\title{
GÖÇÜN ELLİNCİ YILINDA ALMANYA'DA YÜKSELEN DEĞER: TÜRK-ALMAN GÖÇMEN YAZINI
}

\author{
Hikmet ASUTAY ${ }^{1}$ \\ Tuğba ÇARIKÇI ${ }^{2}$
}

\begin{abstract}
Öz: Bu çalışmada; altmışlı yıllarda Türkiye'den Almanya'ya işçi göçü ile birlikte oluşmaya başlayan Türk-Alman, ya da eski adıyla dışgöç yazınında ikinci kuşak dönemi konu alınmıştır. Çalışma, göç kavramının tanımlanması ve artık günümüzdeki adının tanımlanmasıyla başlayıp, Türk-Alman dışgöç yazınının tarihsel gelişimi ile ilgili verilen genel olarak tanıtılması ile devam etmektedir. Daha sonra, konunun sinırlılığ açısından seksenli yıllara denk gelen ikinci kuşak dönemi ve yazarları ile bu yazarlardan biri olan Renan Demirkan ve Üç Şekerli Demli Çay adlı eseri örnekleme bağlamında kimlik arayışı açısından ele alınmıştır. Yazar Renan Demirkan ve eserinin seçilmesinin nedeni, ikinci kuşak göçmen yazını özelliklerini yansıttığı ve ana konusu olan kimlik arayışını dillendirdiği içindir. Türk-Alman yazınına farklı bir açıdan, dönemin önemli bir yazarı ve eserinin incelenmesi açısından irdelemeyi amaçlayan çalışmamızda "vatan hasreti, uyum" gibi kavramlar incelenmeye çalışılmışıır. Dönemin eserlerinde yansıtılan bu kavramların barındırdığı derin anlamlar, farklı bir ülkede karşılaşılan öteki kültür, farklı gelenek ve görenekler ile öteki dil söz konusudur. Sonuç bölümünde, dışgöç yazınının başladığı günden Türk-Alman yazını adını aldığı günümüze nasıl değişiklik geçirdiği, yazında kullanılan kavramların eserlere işlenişi, göçle gittikleri başka bir ülkede yaşamla mücadele ederken bu yazın türünün nasıl ortaya çıktığı, seçilen örnek bağlamında anlatılmaya çalışılmış, özelde de Türk-Alman göçmen yazını ikinci kuşağın belli başlı yazınsal özellikleri ile ele aldığı konular, örnek metin bağlamında irdelenmeye çalışılmıştır.
\end{abstract}

Anahtar Sözcükler: Göç, Dışgöç Yazını, Edebiyat, İkinci Kuşak, Renan Demirkan.

\section{Giriş}

İş gücü açığını kapatmak amacıyla Almanya, çeşitli ülkeler ile 1955 yılında yapılan ikili anlaşmalarla Almanya'ya işçi göçü başlamıştır. Türkiye bu gruba

\footnotetext{
${ }^{1}$ Doç. Dr., Trakya Üniversitesi, Eğitim Fakültesi, Yabancı Diller Eğitimi Bölümü, Alman Dili Eğitimi Anabilim Dalı. hikmetasutay@yahoo.de

${ }^{2}$ Yüksek Lisans Öğrencisi, Trakya Üniversitesi, Sosyal Bilimler Enstitüsü, Yabancı Diller Eğitimi Anabilim Dalı. Alman Dili Eğitimi Bilim Dalı.tugbacrk@hotmail.com
} 
30 Ekim 1961'de imzalanan Ankara anlaşması ile dâhil olmuştur. Öncelikle geçici bir çözüm olarak bakılan bu konuk işçilerin ${ }^{3}$ sayısı gün geçtikçe artmış ve sanılanın aksine geri dönüşler düşünüldüğü gibi gerçekleşmemiştir. Geçici bir süreliğine para kazanmak, ailelerine para yollayabilmek için kalkışılan bu iş, zamanla "ha bugün, ha yarın" dercesine kesin dönüş fikri ötelendikçe ötelenmiş ve başta düşünülmediği kadar uzamıştır. Zaman içersinde "burada kalabilir miyim?" sorusunu akla getirmiş ve bu yolda girişimler gerçekleşmesine neden olmuştur. $\mathrm{Bu}$ tür girişimlerin en önemlisi Alman vatandaşlığına geçiştir. Misafirlik yerini ev sahipliğine bırakmıştır. İlk başlarda çekilen tüm zorluklara rağmen Almanya' da kalma fikri birçok kişiye o zorlukları yaşadıktan sonra geri dönmeme kararını aldırmıştır. Bunda da en büyük etken, orada doğan veya Türkiye'den gelip orada yetişen işçi çocuklarının yarattığı yerleşik düzendir. Dönemin Alman hükümetince kesin dönüş için çeşitli teşvikler yapılsa da beklendiği kadar büyük bir kesin dönüş dalgası yaşanmamış, yapanların da özellikle çocukları, anavatana uyum sorunu yaşadıklarından Almanya'ya geri dönmüşlerdir ${ }^{4}$. Ancak Almanya'daki Türklerin çoğunluğu için kalış süreci kendiliğinden, uzun erteleyişlerin sonucunda oluşmuştur. Belli bir yaşa gelen ve hatta emekli olan insanlarımız, Almanya'da uzun yıllar boyu (otuz-kırk yıl gibi) alışık oldukları düzen ve yaşam tarzını bırakmak istemediklerini fark etmişlerdir. Gerekçelerin başında da Almanya'da sunulan sağlık hizmeti gelmektedir. Üstelik memleketleri olan ana yurda her geçen gün biraz daha yabancılaştıklarını da fark ettikleri için, yeni yurtları olan Almanya'dan aslında kopamayacaklarını da anlamaya başlamışlardır. Bu kesin dönüş ya da kalış sürecindeki en önemli etkenlerin başında ise çocukları ve çocuklarının tercihleri gelmektedir. Zira çocukları kendileri gibi geçici olarak gelmemişler, tersine orada doğup büyümüşler, orada okullara gitmeye başlamışlardır. Sonuç olarak da orada çalışmaya başlamışlardır. Pek çoğu gibi birinci kuşak insanlarımız bu nedenlerle çocuklarının da vatanı olan gurbeti, vatan etmeye başlamışlardır.

Geçicilik ve kalıcılık düşünceleri doğaldır ki yaşam tarzlarının en küçük ayrıntılarına kadar yansımıştır gurbetçi insanlarımızın. Altmışlı ve yetmiş̧i yıllarda birinci kuşağın döneminde Almanya'daki oturumlar geçici olarak görüldüğünden, gereksiz masraflardan kaçınılır, genellikle kullanılmış ikinci el eşyalar alınır, hatta insanlar mutfaklarından keserlerdi, parasal birikim yapabilmek için. Kalıcılık fikrinin egemen olmaya başladığı seksenli yıllardan itibaren ise önce eşyalar değiştirilmiş, sanat ve kültürle daha çok ilgilenilmiş

\footnotetext{
${ }^{3}$ Geçici oldukları düşünüldüğü için o dönemde Almanca "Gastarbeiter” olarak adlandırılmış, ülkemizde de "Gurbetçiler" olarak bilinmektedir.

4 1983'de çıkarılan bir yasa ile 30 Ekim 1983 ile 30 Haziran 1984 tarihleri arasında Türk işçilerinin geri dönmeleri durumunda kendilerine 10.500 Mark, ayrıca reşit olmayan her çocuk için de 1.500 Mark tazminat verilecekti. Ayrıca geri dönen ailelerin çocuklarına yönelik, ülkelerine uyum sağlayabilmeleri için yardımda bulunmak üzere bir kültür anlaşması da imzalandı (Kaya 2000, s. 49-50). Bu yasa Türk işçileri tarafindan fazla rağbet görmese de 1984 yılında yaklaş1k olarak 250.000 Türk işçisi yurda kesin olarak dönmüştür (Abadan-Unat 2002, s. 75).
} 
hatta kiracılıktan çıkıp kredi alarak ev sahibi olma hareketleri görülmeye başlamıştır. Böylelikle parasal anlamda da tersine bir göç yaşanmaya başlamıştır. Önceleri Türkiye'ye para gönderme son derece olağan iken, kalıcılık süreci ile birlikte yatırımların yeri Almanya olmaya başlamıştır. Türkiye'den geliri olan insanların da gelirlerini Almanya'ya aktarmaya başladıkları da görülmüştür. Bugün için de Türkiye'deki örneğin kira gelirlerini toplayıp Almanya'da kendisi ve ailesi için harcayan insanlar bulunmaktadır. Almanyalı Türklerin içinde çoğunluğunu birinci kuşak insanlarımızın oluşturduğu bir emekliler kesimi vardır ki, yılın çeşitli zamanlarını Türkiye'de geçirirken, diğer zamanlarını da Almanya' da geçirmektedirler.

Kısa fakat çok anlamlı bir sözcük olan "göç" kavramının Almanya'ya göç eden Türkler için anlamı, daha önce göç etmemiş insanlarla kıyaslandığında asla anlaşılamayacak ölçüde bir anlam genişlemesine uğrayarak, ellinci yılını kutladığımız bugünlerde elli yıllık bir yol ve yaşam öyküsüne dönüşmüş, üstelik kendi süreci içersinde üç kuşak yetişmiştir;

İş gücü istemişlerdi ama insanlar geldi. Gelenler ülkedeki refahı bozmuyorlardı, tersine refahın sürdürülebilmesi için gerekliydiler. Ama buradaydılar işte.

Konuk işçi mi bunlar, yoksa yabancı işçi mi? (Max Frisch: Karakuş / Kuruyazıcı 2001, s. 4).

Konuk mu yerleşik mi sorgulamalarının başladığı noktada tüm bu göç serüvenini konu edinen göçmen yazını ve dolayısıyla göç kavramının da yeniden tanımlanması gerekliliği ortaya çıkmıştır. Almanya'daki gurbetçilerimiz bağlamında göçmenlik sürecinin kendi doğası gereği başta sözü edilen geçicilik konusu gereği, bu toplumun yazını da konuk işçi yazını olarak nitelendirilmiş ama daha sonraları değişen koşullarla birlikte bu yazının da adı bir takım değişimlere uğramaya başlamıştır.

\section{Göç Kavramının Tanımı}

İnsanların bulundukları yerleşik düzenden başka bir yerleşik düzene geçmeleri demek olan "Göç", çok eskilere dayanmaktadır. İlk yerleşik düzene geçen Türk devleti olma özelliği taşıyan Uygurlar'dan önce ve sonrasında da devam eden bu kavram yeni yaşam alanı arayışları, bulunulan yerlerin olanaklarının yetmemesi, dış baskılar gibi birçok faktörün tetiklemesiyle gerçekleştirilmiştir:

Göç, genel bir anlatımla kişilerin yaşamlarının gelecekteki kısmının tamamını veya bir parçasını geçirmek üzere, tamamen ya da geçici bir süre için kent kasaba köy ya da büyükşehir gibi bir yerleşim biriminden bir başka birime yerleşmek amacıyla yapılan coğrafi yer değiştirme olayıdır. Kısaca göç kavramı birçok faktöre bağlı ve farklı nedenlerle insanların oturduğu bir yeri, kesin bir şekilde ya da geçici sürelerle terk etme olgusunu açıklamaktadır (Tuncay 2010, s. 1-30).

$\mathrm{Bu}$ bağlamda göç; "insanların yerleşik bir düzenden diğer yerleşik bir düzene geçebilmek için yaptıkları eylemdir" (Tuncay, 2010, s. 20) tanımını çalışmamızda temel olarak alabiliriz. Çünkü gurbetçi insanlarımızın da daha çok 
parasal nedenlerle yerleşik oldukları Türkiye'den Almanya'ya geçtikleri yerleşik düzen de göçtür.

\subsection{Göçmen Yazınının Almanya Macerası}

Aslında çok geniş bir konu olan bu başlıkta ikinci kuşak yazarlarından Renan Demirkan'a gelmeden, kısaca ve genel hatlarıyla bir fikir oluşturabilmek amacıyla Türk-Alman göçmen yazını hakkında birkaç tarihsel açıklamayla değinmekte yarar olduğu düşünülmektedir. Türk Alman Göçmen Yazını, Türk işçilerin Almanya'ya ilk göçleri ile birlikte altmışlı yılların başında başlar, denebilir. En azından bu yazının birinci kuşak olarak adlandırılan ilk dönemi, altmışlı yıllardır. 1961 yılında Almanya'nın iş gücü açığını kapatmak amacıyla Türklerin Almanya macerası başlamıştır. Yapılan ikili anlaşmalara göre çoğunluğu Türklerden oluşan birçok yabancı vatandaş Almanya'ya gelecek ve savaştan yeni çıkmış olan Almanya için yeni iş gücünü oluşturacaktı. Yabancı konuk işçiler gelecek ve iş gücü açığı kapatıldıktan sonra geri dönecekleri düşünülmüştü. Ancak ilerleyen yıllarla birlikte gelişmeler düşünüldüğü gibi olmadı. Konuk olarak gelen yabancı işçilerin hepsi geri dönmemiş, giderek sayıları artmış, geçici oturum süreleri ise sürekli uzamış hatta süresiz olmuştu. Artık göçmen olan bu insanlar kendilerine orada, öteki kültür içinde yepyeni bir hayat kurdular. Almanya'da her şey farklıydı. Farklı bir kültür, farklı yaşam tarzları ve bambaşka bir dil. Onlar da yazmaya başladılar. Bu aşamada konuları da elbette vatan özlemi, orada yaşadıkları zorluklar gibi konular olmuştur. Farklı bir ülkede çalışmaya çalışırken ayrıca oranın iklimine de uymak zorundaydılar. Uyum sorunu da ana konuları oldu onların. Önceleri bir edebiyat amacı gütmeden başladı bu yazma ihtiyaçları. Söylenildiği gibi bir ihtiyaçtı bu; başka ülkede yaşanılanları aktarmak için belki de ama daha sonra gelişti, büyüdü ve bir yazın halini aldı bu aktarmalar. Tüm bu yazılıp çizilenler bir bütün oluşturarak dışgöç yazınını yani bugünkü Türk-Alman yazınını çıkardı ortaya.

$\mathrm{Bu}$ bağlamda genel olarak Türk-Alman Göçmen Yazınında üç evreden söz edilebilir: Birinci kuşak, ikinci kuşak ve üçüncü kuşak. Yukarıda değinilen anavatandan Almanya'ya yani gurbete gidiş, farklı kültürle ilk karşılaşma, dil ve iletişimsizlik, vatan hasreti gibi konular birinci evrenin belli başlı konuları olmuştur. Kavramsal olarak da Almanya'da ilk önceleri Türkçe olarak yazılan metinler çıkar ortaya ki tüm bu yazınsal birikime bir ad bulmak gerekmektedir. Birinci Kuşak olarak tanımlanan Türk yazarlar altmışlı yılların sonlarına doğru ilk yazınsal eserlerini vermeye başlamışlardır. Bu kuşağı temsil eden öncü yazarlar; Yüksel PAZARKAYA, Nevzat ÜSTÜN, Bekir YILDIZ, Fakir BAYKURT, Aras ÖREN, Habib BEKTAŞ, Şinasi DİKMEN, Fethi SAVAŞÇI, Güney DAL v.d.'dir.

\section{Adlandırılamayan Yazın}

Yukarıdaki bölümlerde sözü edilen geçicilik ve kalıcılık duyguları nedeniyle ilk önce geçici olarak görülen bu göç sürecinin dolayısıyla yazını da benzer bir mantıkla konuk işçi yazını şeklinde bir ad ile adlandırılmıştır. Daha önce 
Türkiye'de yazar olan ve konuk işçi olarak Almanya'ya gelen Türk yazarlar da vardır ve bunlar birinci kuşağı oluşturmaktadır. Öncelikle sadece yaşadıkları sıkıntıları gidermek, rahatlamak ve yukarıda anılan birinci kuşağın konularını dile getirmek amacıyla bir şeyler karalamaya başlamışlardır. Zamanla bu çalışmalar hemen adlandırılamayacak bir yazın türü haline gelecektir. Fakat ortaya çıkan bu yazına ne ad verileceği konusunda genel geçer olarak tam bir kavram bulunmamaktadır o dönem için. Konuk işçi yazını demek olan "Gastarbeiterliteratur" sözü ile başlayan kavram arayışı Türk ve Alman yazınbilimcilerce birçok kez farklı kavramların önerilmesi ile devam etmiştir:

Yabanc1lar edebiyatı (Ausländerliteratur),

azınlıklar edebiyatı (Minderheitenliteratur),

kültürlerarası edebiyat (Interkulturelle Literatur),

çokkültürlü edebiyat (Multikulturelle Literatur),

göçmen edebiyatı (Migrantenliteratur) vb. (Zengin, 2000, s. 105).

Yine de önerilen tüm bu kavramların hiç birinin tam olarak bu yazını karşıladığı söylenemez. Ancak Türkiye'de bu yazın türü daha çok "Dışgöç Yazını”(Bkz. Karakuş / Kuruyazıcı 2001 vd.), Almanya'da ise artık tarihsel olarak adlandırılan "Gastarbeiterliteratur" terimi, yerini "Deutsch-Türkische Literatur" yani "Türk-Alman Yazını" terimine bırakmıştır. Ayrıca farklı kişi veya kurumlar nezdinde de Türk-Alman Göçmen Yazını olarak da anılabilmektedir. Tüm bu kavram arayışlarının altında yatan neden, aslında Türk-Alman göç sürecinin kendi içindeki değişken koşullarıdır. Geçiciliğin hâkim olduğu dönemde, bu sürecin yazını da başına Almancasında geçici (Gastarbeiter konuk işçi yazını gibi) ön adı almış, kalıcılık fikriyle birlikte Türk-Alman yazını olarak anılır olmuştur. Elbette bu yeni dönem yazının geçmişi de göz önüne alınırsa Türk-Alman göç yazını tarihsel olarak da belli bir grubun dönemsel aşamalarla oluşturduğu yazını işaret etmektedir. Tek başına Türk-Alman yazını deyimi ise daha çok Alman yazınbilimcilerinin, göçmen yazınının Almanca yazan son dönem yazınını Alman yazını içersinde saymak istemelerinden kaynaklanmaktadır (Karakuş / Kuruyazıcı 2001, s. 6). Bu çalışmada yalnızca ikinci kuşak yazarlarından Renan Demirkan ele alınacağından, dönem olarak da Türk Alman göçmen yazınının ikinci kuşak evresi üzerinde durulacaktır.

\subsection{Göçmen Yazınında 80li Yıllar ve İkinci Kuşak}

Aslında bu ayrımı yapmak oldukça zordur. Sözgelimi 60'lı, 70'li ve 80'li yıllar olarak ayırmak mı; birinci, ikinci, üçüncü kuşak olarak adlandırmak mı, yoksa yazarların doğum tarihleri yahut eser verdikleri döneme göre ayırmak mi, daha doğru olur, bu konu hala tartışılmaktadır. Yine de adlandırılması ve sınırlandırılması adına ikinci kuşak ya da 80'li yıllar olarak da kullanılan bu dönem, gerek yazarları, gerekse verilen eserler olarak oldukça zengin bir dönemdir. Bu çalışmada da ortaya konan eserler ve eserlerin oluştuğu zaman dilimi göz önüne alınarak ikinci kuşak ve 80'li yıllar aynı evreyi işaret eder ölçüde eşanlam olarak kullanılacaktır. 
İkinci kuşak yazarlar, Almanya'daki Türk toplumunun ve dolayısıyla Türk Alman göçmen yazını yazarlarının dâhil olduğu birinci kuşak yani Türkiye'den kalkıp Almanya'ya göç eden gurbetçilerimizin çocuklarıdır. Bu çocuklardın kimi Almanya'da doğmuş, kimi de Türkiye'de doğmuş olan ve kimi de daha sonra aileleri ile birlikte Almanya'ya henüz çocuk yaşlarda gidenlerdir. Birçoğu da önce ebeveynlerinin gittiği Almanya'ya sonradan "istek" ile gidenlerdir. Bu grup, bölünmüş aile özellikleri de gösterir. Bu çocukların neredeyse tamamına yakını Almanya'da büyüdüğünden ve eğitim aldıklarından, Almanya'ya çok daha fazla uyum sağlamış, dil ve kültürünü çok daha çabuk ve daha iyi öğrenmiş insanlardır. $\mathrm{O}$ yüzden içlerinden çıkan yazarların pek çoğu eserlerini Almanca olarak yazmışlardır. Yalnız bu kuşağın eserlerinde ele aldıkları konu yelpazesi, birinci kuşağa göre oldukça farklı ve yeni bir sorundur: Modern bir sorun olarak da tanımlanabilecek olan yabancılık sorunu ile kimlik sorunu. $\mathrm{Bu}$ insanlar bu toplum içinde büyümelerine rağmen, toplumun geneli tarafindan kendilerine ait olarak değil, "yabancı" olarak adlandırılmaktadır. Üstelik "memleket" adını verdikleri ebeveynlerinin anayurduna izne gittiklerinde orada da aynı yakıştırmayı duymaktadırlar. Bu da bu ikinci kuşak insanların yabancılık sorunu yaşamalarına neden olmakta, kimlik sorgusu yaparak ne tarafa ait olduklarını sorgulamaktadırlar. $\mathrm{Bu}$ anlamda hiçbir tarafa ait olamamanın yarattığı gerilim, bu insanları kimlik bunalımlarına doğru itmiştir. Diğer bir taraftan da kendileri gibi olan yaşıtlarıyla bir araya gelerek, içinde bulundukları toplum bütününden farklı, kendi içinde benzer nitelikleri olan bir alt-kültür grubu oluşturmuşlardır. Kendi lokantaları, kahvehaneleri, dernekleri vb. gibi alt kültür özelliklerini taşıyan ortak yerler de oluşturabilmişlerdir.

Yabancılık veya kimlik sorunu vb. gibi konularıyla ikinci kuşak dönemi yazarları, Almanların ilgisini fazlasıyla çekmiştir. İki dilli olarak yetişen bu yazarlar Almanca düşünebiliyor ve eserlerini Almanca veriyorlardı. Konuları genellikle kültürlerarasılık ve ortaya çıkardığı sorunlar üzerineydi. İkinci kuşak yazarlardan bazıları ${ }^{5}$ şunlardır: Renan Demirkan, Feridun Zaimoğlu, Zafer Şenocak, Zehra Çırak, Saliha Scheinhardt, Aysel Özakın, Nevfel Cumart, Alev Tekinay, Levent Aktoprak ${ }^{6}$. Bu kuşak yazarlardan biri de Renan Demirkan'dır. Bu kuşağın dönemini, bir takım dönemsel özellikleri daha yakından görebilmek amacıyla R. Demirkan ve eserlerine genel bir bakış açısıyla değinmekte yarar vardir.

\subsection{Seksenlerin Göçmen Yazını Yazarlarından Bir Örnek: Renan Demirkan}

Göçmen bir ailenin kızı olan Renan Demirkan, tiyatro sanatçısı ve yazardır. Büyük Çerkez sürgününde Düzce yöresine yerleşmiş bir Adige ailesinin kızıdır.

\footnotetext{
${ }^{5}$ Seksenli yıllarda gelen ikinci kuşak yazarları grubunun önde gelen temsilcileri Habib BEKTAŞ, Şinasi DİKMEN, Yaşar MİRAÇ, Fethi SAVAŞÇI, Yücel FEYZİOĞLU gibi yazar ve Şairlerdir.

${ }^{6}$ Ayrıca bu dönem içerisinde Aras ÖREN, Yüksel PAZARKAYA, Kemal KURT'un yanı sıra sonradan göç eden Emine Sevgi ÖZDAMAR, Şinasi DİKMEN ve Almanya'da yetişmiş Zafer ŞENOCAK, Yade KARA ve Hatice AKGÜN gibi yazarları da görmekteyiz (Yalçın 2011, s. 7).
} 
1955 yılında Ankara'da doğmuş, 1962 yılında ailesiyle birlikte Almanya'ya göçmüştür. Öğrenimini Almanya'da yaparak Hannover Müzik ve Tiyatro Yüksek Okulu'nu bitirmiş ve halen Almanya'da yaşamaktadır. Tiyatro'ya 1980 yılında başlamış ve 1982 'de ilk filmini çevirmiştir. Sayısız tiyatro oyunu ve filmde başrol oyuncusu olarak rol alan sanatçı, Alman Televizyonunda Reporter adlı dizideki Gazeteci Azade rolüyle zirveye tırmanmıştır. NRW Eyalet Ödülü’nü (1986), Halkın Seçtiği Altın Kamera (1990) ve eleştirmenlerin verdiği Adolf Grimme Ödülü'nü kazandı ${ }^{7}$.

1991 y1lında Almanya'da yayınlanmış bulunan Schwarzer Tee mit drei Stück Zucker adlı romanı Türkçe'ye de çevrilerek Üç Şekerli Demli Çay adıyla yayınlanmış ve on kadar baskısı yapılmıştır. Die Frau mit Bart (Sakallı Kadın) adlı romanı da 1994 yılında Almanya'da yayınlanmıştır. 1989 yılında Goldene Kamera (Altın Kamera), 1990 yılında Adolf Grimme Ödülü, 1998'de ise Alman Cumhurbaşkanı Roman Herzog'tan "Bundesverdienstkreuz", 2002 yılında da INTHEGA Tiyatro Ödülü’nü almıştır.

Düşüncelerini en iyi Almanca olarak ifade ettiğini söyleyen Renan Demirkan, birçok tiyatro oyununda oynayıp, film yapıp bu alanlarda önemli ödüller kazandıktan sonra yazın dünyasına da giriş yapmıştır. Renan Demirkan'ın yazmış olduğu bazı kitaplar şunlardır:

Schwarzer Tee mit drei Stück Zucker (1991) (Türkçe Çev. Üç Şekerli Demli Çay)

Die Frau mit Bart (Türkçe Çev. Sakallı Kadın 1994)

Der Mond, der Kühlschrank und ich. Heimkinder erzählen (2001)

Es wird Diamanten regnen vom Himmel (2001).

Über Liebe, Götter und Rasenmähn (2003)

Septembertee oder das geliehene Leben (2008)

Sanatçı Renan Demirkan'ın yalnızca Üç Şekerli Demli Çay adlı Türkçe’ye de çevrilen eserine göndermeler yapılarak, kısaca dönem açısından ikinci kuşak ya da 80li y1llar dönemine değinilecektir.

\subsection{Schwarzer Tee mit drei Stück Zucker ( Üç Şekerli Demli Çay)}

Kendisi de göçmen bir ailenin kızı olan Renan Demirkan, bu eserinde Almanya'ya göçü, anılan bu göç sürecinde çekilen zorlukları ve farklı bir topluma uyum sorunlarını anlatmaktadır. Dili oldukça akıcı, konu olarak aslında bilinen, fakat oldukça zengin olan bu eser, göç kavramına karşılaştırmalı bir bakışı mümkün kılmaktadır.

Ankaralı orta sınıf bir ailenin Almanya'da yetişen kızının öyküsüdür. Demirkan bu eserinde, 1962 yılında Almanya'ya çalışmak için göç eden ailesinden, oradaki yaşam biçimi, çektiği zorluklar ve uyum problemlerinden söz eder. Yazar, Alman dilinde kendini daha rahat ifade edebildiğini söylese de, "yabanc1 olma" duygusunu zaman zaman dile getirmektedir. Eserdeki sorunun temelinde

\footnotetext{
${ }^{7}$ http://www.e-kafkasya.com, Erişim Tarihi: 02 Şubat 2012.
} 
hem yabancı olma, hem de kadın olma konumu çarpıcı bir biçimde verilmektedir. Eserde, çeşitli karşıtlıklara dayanan söylemler yeniden üretilir: Kadın-Erkek, Doğu-Batı, Müslüman-Hıristiyan gibi kutupluluk veya karşıtlık ya da karşılık olabilecek bir takım kavramlar bir araya getirilerek Türk Alman bağlamında ifade edilmiştir. Eserde çoğu kez Türk ve Alman imgelerinin iç içe geçtiği görülür.

Üniversite öğrenimi gören ikinci kuşak Türkler arasında yer alan yazar, bu eserinde her iki kültürdeki yaşam biçimi ve şartlarını, inançlarını, kültürel değerlerini, günlük yaşam içerisinde karşılaştırmalı olarak vermeye çalışmıştır; "Eserde, göçmenlik, yabancilık, kimlik sorunu ve bununla beraber evrensel konular da işlenmektedir", diyen Sağlam, yazarın söz konusu üzerinde geniş bir inceleme yaparak Türk ve Alman imgelerini karşılaştırmıştır (Bkz. Sağlam, 2006 ). Eserin tamaminda, vatana duyulan hasret buram buram hissedilmektedir;

Ninesinin, güzel kokulu tülbendini hatırlaması" ya da "Memlekete ve doğaya duyulan özlem, Almanya'da evlerde giderilmeye çalışıllyor. Orada su mavisi keçenin döşenmesi, sıcak yeşil ve kum tonlarında el dokuma kilimlerin yayılması, yeşil mavi saten perdeler, tavana kadar palmiyeler yerleştirme (Demirkan, 1991)

ifadeleri vatana özlemin en açık kanıtlarından bazılarıdır. Bu özlem kitabı saran, vatanı hatırlatan bir koku gibi okuyucuyu da etkiler. Eserde birinci kuşağı temsil eden ebeveynlerinin bakış açılarını (başkişinin annesinin ağzından) dile getirerek, birinci kuşak yazarlarında sıkça konu edilen yabancılık olgusuna da göndermeler yapılır:

"Burada biz yabancıyız" diyerek çocuklara "uslu" olmaları için yükleniyordu. Kızlar ne okul gezilerine, ne de öğrenci şenliklerine katılabiliyordu. Zamanla anlayacaksınız. Bir insan hiçbir zaman kökünü terk etmemeli. Burada hep yabancı olarak kalacağız (s. 29).

Burada dile getirilen yabancılık olgusu, öteki kavramını da doğurmaktadır. Yabancı olarak Türkler öteki gibi davranmayıp, kendi gelenek, görenek, inanç ve kültür özelliklerine göre davranmalıydılar. Bu konuda ise en çok Türk kızları baskı altındaydılar. Öteki ile büyük farklılıklar yine en çok Türk kızlarının yaşamında görülmekteydi:

Anne sadece: "Artık kadınsınız" diyordu. Tehdit edici bir şey vardı bu sözde.

Komşu çocuklarıyla hoplayıp zıplayamıyorlar, banyo yaparken kapıyı kapatmaları gerekiyor, kısa etekler uzatılıyor... Gittikçe daha kapalı ve daha utangaç oluyorlardı. Onlar ancak en yakın çevrede bisikletle turlayabilirken, okul arkadaşları flört ederek, daha kısa eteklerle, utanmadan gençlerle okul bahçelerinde ve caddelerde koşuşturuyorlardı. ... Düşlerinde her biri, kendi ailelerinden daha değişik yeni bir aile yaratıyorlardı (s. 36).

Dile getirilen tüm bu kalıplara uymayan Türk kızlarını ise büyük yaptırımlar hatta cezalar bekliyordu: 
Maddi olanakları, ev geçimi için tamamen yetersizdi. Yurda ihanete, katı cezalar olasıydı: Okuldan derhal kaydı silinip Türkiye'ye geri gönderilebilir, ilk çıkan erkekle evlendirilebilir veya hastanelik oluncaya kadar dayak yiyebilirdi (s. 42).

Eserde sıkça karşımıza çıkan Türk- Alman çocuklarının yetişme tarzı, ergenlerin aynı sorunlar karşısında kültürel farklılıklar nedeniyle farklı tepkilerle karşılaşmaları dile getirilerek ruh hallerine de yer verilmiştir. Bir başka konu da kültürel etkileşimdir. Yabancı olan kesim, "öteki”nden işine yarar özellikler edinebilmiştir, örneğin:

Her iki toplumun en iyi özelliklerini seçtim, Bir Alman olarak disiplin, çalışma hırsı ve hayallerim için çalışmayı öğrendim. Türk olarak ise, maneviyata önem vermeyi, küçük şeylerle mutlu olabilmeyi ve her şeyi fazla ciddiye almamayı öğrendim. iki kültürden de benim için en iyi olan seçtim (s. 5).

İkinci kuşak döneminin karakteristik özelliği olan kimlik bunalımı, iki arada olma duygusu bu eserde de kurgu boyunca hissedilmekte birçok yerde de doğrudan dile getirilmektedir:

Kendimi ikiye ayrılmış gibi duyumsuyorum. Bir parçam burada, içeride hep sözünü duyduğum o "sarı havaya, diğer parçam ise her gün yaşadığım çevreye ait. Vatanın ne olduğunu bilmiyorum. Belki düşmemek için bir tutanak (s. 52).

Tabi yabancılaşma yalnızca Almanya için bir olgu değildir ikinci kuşak için. Kendi anavatanlarına, memleketlerine karşı da yabancılaşma söz konusudur:

O yabancı kelimesinin hüzünlü, aynı zamanda zavallı bir tonu vardı. Bu yalnızca kendini burada yabancı hissettiğinden değil, yerliler tarafından yabancı olarak gerçekte onay görmemesinden ve kendi ülkesinde de giderek yabancılaşmasındandı (s. 29).

Çoğu ikinci kuşak yazarlarının ortak konusu olan yabancılaşma sorunsalı, görüldüğü üzere Renan Demirkan'ın eserinde de ağırlıklı olarak gözlemlenebilmektedir. Üstelik bu yabanc1laşma olgusu gündelik yaşamdaki çeşitli olay veya gözlemler ekseninde dile getirilmiştir. Renan Demirkan konusunda yüksek lisans tezi hazırlamış olan araştırmacı Nurhayat Yalçın, yazardan yola çıkarak şu tesbiti de yapmaktadır:

Eserde (Ü̧̧ Şekerli Demli Çay) ayrıca bir zamanlar işçi olarak Almanya'ya giden vatandaşlarımızın ve onların çocuklarının çok çalışarak mühendis, sanatçı, mimar, hukukçu gibi meslek dallarında eğitim gördüklerini ve bu alanlarda başarı gösterdiklerini görüyoruz. Bunun dışında siyasi konularda da gençlerimiz fikirlerini söylüyorlar ve kendilerini rahat bir şekilde ifade ediyorlar. İkinci ve üçüncü kuşak gençlerimiz artık Almanya'ya uyum sağlamıştır ve her alanda Alman gençleriyle yarışır duruma gelmişlerdir. Ancak bundan rahatsız olan Almanlar Almanya'ya göçün 50. yılında hala yabancılara karşı düşmanlık beslemekteler ve insanlarımızın ölümüne neden olmaktalar (Yalçın 2011, s. 107).

Yalçın burada başarılı bir göç hikâyesinin yanında, Alman toplumunda var olan ve son yıllarda giderek artan (küçük bir azınlık da olsa) yabancı düşmanlığı konusuna değinmektedir. Ancak görülen o ki, gurbetçilerimiz bu ve benzeri olaylar nedeniyle yılmamakta, kendilerini o toplumun bireyleri olarak görüp, başarılı da olabilmektedirler. 


\section{Sonuc}

İlk başta geçici olarak tasarlanan Türklerin Almanya'ya göçleri ve oradaki çalışma amaçlı ikametleri, kalıcılık, yerleşme ve sonunda da uyum gibi bambaşka bir olgu olarak çıkmıştır ortaya. Bu süreçte Türkler bırakın geri dönmeyi, gittikleri ülkede önemli bir yer edinen bir yazın türü ortaya çıkarmışlardır. Dış göç yazını derken, yazın tarihi açısından kökenine de işaret ederek Türk-Alman göçmen yazını adını almıştır. İkili anlaşmalarla Almanya'daki iş gücünü kapatmak amacıyla Almanya'ya çağrılan işçiler, onların çocukları, belki onların da çocuklarının hayatları konu oldu bu yazının ortaya çıkmasına. Sıkıntı çektiler, şaşırdılar, korktular, mutlu oldular, sevindiler ve yazdılar. Yeni bir yazın türü oluşturdular. Bazıları oraya gitmeden de yazıyordu; birinci kuşak yazarlarında olduğu gibi, bazıları ise orada başladılar. Bazıları hiç yabancı dil bilmiyorlardı ana dilleriyle yazdılar, bazıları öğrendikleri dille. Ama bir şekilde oluştu bu yazın ve tutundu. Renan Demirkan'nın eserinde de görüleceği üzere ne yaşadılarsa onu yazdılar aslında.

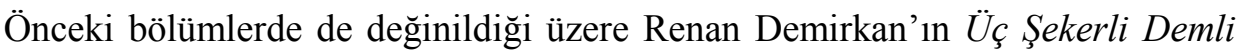
Çay eseri belki de bu yazın türünün küçük bir özeti niteliğindedir. Romanda bahsedilen Türkiye ve Almanya, iki ülkeyi ve bu ülkelerde yaşanılanları karşılaştırma firsatı veriyor bizlere. Ve gösteriyor ki göç etmek sadece başka bir ülkeye gidip yaşamak değil, gidilen ülkede var olabilmek, varoluş mücadelesi verebilmektir. $\mathrm{Bu}$ da sadece bedenen gerçekleşebilecek bir şey değildir. İsteyerek ya da içinde bulunulan şartlar gereği göç etmenin ne kadar zor bir şey olduğunu anlatmayı amaçlayan bu çalışma, Türk-Alman göçmen yazınının ikinci kuşak dönemine Renan Demirkan'ın Ü̧̧ Şekerli Demli Çay eseri aracılığıyla genel bir bakış sunmayı amaçlamıştır. Göç kelimesi Türkler için göçün ellinci yılında da aynı anlamlılığını sürdürmekte midir, bilinmez, ancak yarım yüzyıllık bir hikâye, yarım yüzyıllık bir kültür birikimi çoktan oluşmuş ve devam etmektedir. İşte bu öykünün son bölümü yine bu göçün birinci ve ikinci kuşak insanlarının bizzat yaşadıklarının doğrudan anlatımı ile göç sonrası, Türkiye'ye kesin dönüş sürecinden sonra geriye bakışla Fremde Heimat Deutschland (2011) adlı kitapta dile gelmektedir (Ham / Kubanek 2011). Bu olguyla Türk-Alman yazınında Türkiye odaklı bir "Remigranten"(kesin dönüşçüler) kavramı (Bkz. Asutay 2011, s. 100-107) yeni bir inceleme ve tartışma konusu olarak karşımıza çıkmış bulunmaktadır. Sonuç olarak yazar Demirkan, Türk-Alman göçmen yazını yazarlarından biri olarak çok yeni değil, aksine eserleri üzerine pek çok bilimsel çalışma yapılmış ve yapılan yazarlarımızdan biridir. Bu anlamda Renan Demirkan penceresinden yeni bir bakış oluşturmak hedeflenmiştir. 


\section{KAYNAKÇA}

Abadan-Unat, N. (2002). Bitmeyen Göç. İstanbul: Bilgi Üniversitesi Yayınları. Asutay, H. (2011). "Eine lange Geschichte von der Autobahn E-5 in Jugoslawien" in: HAM, Murat und KUBANEK, Angelika. (2011). "Fremde Heimat Deutschland". Stuttgart: Ibidem Verlag.

Cengiz, S. (2010). "Göç, Kimlik ve Edebiyat". Zeitschrift für die Welt der Türken, 2 (3), S. 185-193. Erişim Tarihi: 12 Mart 2012, http://www.dieweltdertuerken.de/index.php/ZfWT/article/viewFile/174/s_cengiz.

Ekiz, T. (2007). Avrupa Türk Edebiyatı ve Bir Temsilcisi: Emine Sevgi Özdamar. Journal of Arts and Sciences, 7, 34-36.

Ham, M. und Kubanek, A. (2011). Fremde Heimat Deutschland. Stuttgart: Ibidem Verlag.

http://www.e-kafkasya.com/forum/tiyatro/renan-demirkan/?wap2, Erişim Tarihi: 02 Şubat 2012.

http://www.diewelt-dertuerken.de, Erişim Tarihi: 12 Mart 2012.

http://www.renan-demirkan.de/ Erişim Tarihi: 15 Haziran 2013.

Karakuş, M. (2001). Yüksel Pazarkaya ile Göçmen Yazını Üzerine Bir Söyleşi. Gurbeti Vatan Edenler Almanca Yazan Almanyalı Türkler; N. Kuruyazıcı ve M. Karakuş. Ankara: Kültür Bakanlığı.

Kaya, A. (2000). Berlin'deki Küçük İstanbul. İstanbul. Büke Yayınları, 49-50.

Kuruyazıcı, N. (2001). Almanya'da Oluşan Yeni Bir Yazının Tartışılması. Gurbeti Vatan Edenler Almanca Yazan Almanyalı Türkler; N. Kuruyazıcı ve M. Karakuş. Ankara: Kültür Bakanlığı.

Yalçın, N. (2011). Üç Şekerli Demli Çay Romanında Kültürlerarasılık. (Yayınlanmış Yüksek Lisans Tezi). Ankara: Ankara Üniversitesi. Sosyal Bilimler Enstitüsü.

Özyer, N. (2001). Türk Yazınlarının Alman Çocuk ve Gençlik Edebiyatına Katkıs1. Gurbeti Vatan Edenler Almanca Yazan Almanyalı Türkler; N. Kuruyazıcı ve M. Karakuş. Ankara: Kültür Bakanlığı.

Sağlam, F. (2006). “Renan Demirkan'ın Üç Şekerli Demli Çay adlı eserinde yer alan Türk ve Alman imgelerine karşılaştırmalı bir bakış". Milli Folklor. 18 (72). Erişim Tarihi: 09.10.2014, http://www.millifolklor.com/tr/sayfalar/72/09.pdf.

Tuncay, S. (2010). Avrupa Birliği Üyeliği Sürecinde Göç Olgusunun İrdelenmesi ve Almanya Örneğinin Analizi. Türkbilim Dergisi, 2, 1-30. 


\section{Konu Bağlamında Daha Önce Yapılan Bilimsel Çalışmalardan Bazıları ${ }^{8}$ :}

Ackermann, I. (1985). In der Fremde hat man eine dünne Haut... Türkische Autoren der 'Zweiten Generation' oder die Überwindung der Sprachlosigkeit. Zeitschrift für Kulturaustausch, 1.

Ackermann, I. (1995), Türkische Migrantenliteratur im Rahmen der deutschsprachigen Ausländerliteratur. Germanistentreffen Bundesrepublik Deutschland-Türkei-Tagungsbeiträge. Hallstadt: DAAD-Rosch Buch Verlag.

Adıgüzel, A. (2008). Göçmen Edebiyatı Bağlamında Güney Dal ve Zafer Şenocak Kü̧̈ük "g" Adında Biri ve Tehlikeli Akrabalık Romanlarının İçerik Bakımından Karşılaştırılması. (Yayınlanmamış Yüksek Lisans Tezi). İstanbul: Yeditepe Üniversitesi Sosyal Bilimler Enstitüsü.

Asutay, H. (2014). Göçmen Edebiyatı. Yazarlar Sözlüğü - Almanya'da yazan ve yaşayan Türk-Alman Edebiyatı. Edirne: Paradigma Akademi.

Aşık, H. (2006). Almanya'daki Türklerin İçecek Tüketimine İlişkin Görüş Ve Davranışları. (Yayınlanmış Yüksek Lisans Tezi). Ankara: Gazi Üniversitesi. Eğitim Bilimleri Enstitüsü.

Balcı, U. (2000). Alman Dilinde Yazılmış Türk Göçmen Edebiyatının KültürDönüşümsel Boyutları ve Yabancı Dil Olarak Almanca Derslerinde Kullanımı. (Yayınlanmış Doktora Tezi). Adana: Çukurova Üniversitesi. Sosyal Bilimler Enstitüsü.

Balc1, U. (2010). Transkulturelle Dimensionen der deutschsprachigen Literatur Türkischer Migranten und ihre Vermittlung im Daf-Unterricht. (Yayınlanmış Doktora Tezi). Adana: Çukurova Üniversitesi. Sosyal Bilimler Enstitüsü.

Baypınar, Y. (1990). Deutschland - ein türkisches Märchen?, Schlaraffenland als Zielscheibe der satirischen Erzählung Şinasi Dikmens [Bildiri]. Begegnung mit dem „Fremden. Grenzen-Traditionen-Vergleiche. Akten des VII. internationalen Germanisten-Kongress Tokyo. München: Iudicium Verlag.

Berberoglu, P. (1995). Kulturerfahrung im Unterricht; Migrationstexte und ihre Anwendung im DaF-Unterricht. Frankfurt am Main: Peter Lang Verlag.

Biber, Ç. (2010). Saliha Scheinhardt'ın Eserlerindeki Kadın Motifleri. (Yayınlanmış Yüksek Lisans Tezi). İstanbul: Hacettepe Üniversitesi Sosyal Bilimler Enstitüsü.

\footnotetext{
${ }^{8}$ Ayrıca Bakınız: Türk Alman Edebiyatı, kültürleri ve ilişkileri bağlamında bir bibliyografya oluştururken, İstanbul Üniversitesi ile Paderborn üniversiteleri tarafından yürütülen "Türk-Alman İlişkileri ve Kültürel Etkileşim” adlı, Tübitak, BMBF ve Ernst-Reuter Girişimi kurumlarınca da desteklenen uluslararası proje çalışmasından özellikle kültür ve kültürlerarasılık konularında derlenen yayın, tez, bilimsel bildiri vd. verilerden yararlanılmış olup, proje ekibi şu araştırmacılardan oluşmaktadır: Prof. Dr. Şeyda Ozil, Prof. Dr. Mahmut Karakuş, Doç. Dr. Canan Şenöz-Ayata, Doç. Dr. Ersel Kayaoğlu, Dr. Yasemin Dayığlu, Ar. Gör. Barış Konukman, Birsen Özgüder, Lale Dayığlu, İrem Atasoy ve Proje ortağı Paderborn Üniversitesi; Prof. Dr. Michael Hofmann, Inga Pohlmeier, Vanessa Tuncer, Helena Platte, Tobias Zenker, Dr. des. Karin Yeşilada.
} 
Canoğlu, H. D. (2011). Kanak Diline Karşı Kiez Almancasl. Almancadaki Her İki Dil Görüngüsünün Kültür Aktarımı Işı̆̆ında Budun Dilbilimsel Açıdan Incelenmesi. İzmir: Ege Üniversitesi Sosyal Bilimler Enstitüsü; Ankara: Hacettepe Üniversitesi Sosyal Bilimler Enstitüsü.

Cengiz, S. (2009). Almanya'daki Türk Yazarların Romanlarında Kimlik ve Yabancılaşma. (Yayınlanmış Doktora Tezi). Ankara: Hacettepe Üniversitesi Sosyal Bilimler Enstitüsü.

Coşkun, B. (1998). Das Türkenbild in der österreichischen Presse am Beispiel: 'Die neue Kronen Zeitung' und 'Der Standard. Eskişehir: Anadolu Üniversitesi. Sosyal Bilimler Enstitüsü.

Doğan, B. (2000). Emine Sevgi Özdamar'ın "Hayat Bir Kervansaray, İki Kapısı Var, Birinden Girdim, Diğerinden Çıktım” Adl Eseri ile Alev Tekinay'ın "Ağlayan Nar" Adlı Eserinde İçerik Karşılaştırması. (Yayınlanmamış Doktora Tezi). Bursa: Uludağ Üniversitesi Sosyal Bilimler Enstitüsü.

Erdemir, H. (2003). The westernization of Turkey, and Turkish migration to the Federal Republic of Germany. (Yayınlanmış Doktora Tezi). Büyük Britanya, Prifysgol Abertawe: Swansea University Yurtdışı Enstitüsü.

Gürlek, İ. Z. (2009). Yurt Dışındaki Üniversite Öğrencisi Türk Gençlerinin Sosyalleşme Sorunlarl: Viyana Üniversitesi Örneği. (Yayınlanmış Yüksek Lisans Tezi). Ankara: Ankara Üniversitesi Eğitim Bilimleri Enstitüsü.

İnce, H. H. (2012). Şinasi Dikmen ve Osman Engin Eserlerinde Hiciv Üzerine. (Yayınlanmış Yüksek Lisans Tezi). Adana: Çukurova Üniversitesi Sosyal Bilimler Enstitüsü.

Hartl, M. (2009). Der deutsch-türkische Gegenwartsfilm im Genre-Vergleich. Melodram, Komödie, Dokumentarfilm und deren Möglichkeiten und Grenzen in der Aufbereitung der Thematiken von Migration, Integration und multikultureller Gesellschaft. (Yayınlanmamış Bitirme Tezi). Wien: Universität Wien, Publizistik und Kommunikationswissenschaften.

Karataş, H. R. (1999). Almanya'daki Türk Gençlerinin Din Ĕ̈ilimleri. (Yayınlanmış Yüksek Lisans Tezi). İstanbul: Marmara Üniversitesi Ortadoğu Araştırmaları Enstitüsü.

Kazan, Z. (2006). Yurt Dışında Yaşayan Türk Kökenli Çocukların İkidillik Kaynaklı Dilsel Sorunları. (Yayınlanmamış Yüksek Lisans Tezi). İstanbul: Y1ldız Teknik Üniversitesi Sosyal Bilimler Enstitüsü.

Kocadoru, Y. (1997). Deutschsprachige Literatur von Türken, Zwischen Ostwestlicher.

Ästhetik. Eskişehir: Birlik Ofset Matbaacılık ve Yayıncılık.

Kocadoru, Y. (2003). Geçmişten Günümüze Almanya'da Almanca Yazan Türkler ve Emine Sevgi Özdamar. Eskişehir: Rema Matbaacılık.

Kocadoru, Y. (2004). Die dritte Generation von türkischen Autoren in Deutschland - neue Wege, neue Themen. in: Durzak, M. ve Kuruyazıc1, N. Die 
andere Deutsche Literatur Istanbuler Vorträge. Würzburg: Königshausen\&Neumann Verlag.

Koç, Y. (2003). Beş Alman Yazarında Türk ve Türkiye İmajı. Selçuk Üniversitesi Atatürk Illkeleri ve Inkilap Tarihi Araştırma ve Uygulama Merkezi Ata Dergisi, 7, 323-329.

Koç, Y. (1996). Çağdaş Alman Şiirinde Türk İmajı Üzerine Bir Deneme. Pamukkale Üniversitesi Eğitim Fakültesi Dergisi, 90-93.

Koç, Y. (2000). Göçmen Edebiyatında Osman Engin'in Yeri ve Eserleri. Konya: Selçuk Üniversitesi Yayınları.

Kuruyazıc1, N. (1990). Stand und Perspektiven der türkischen Migrantenliteratur unter dem Aspekt des ,Fremden' in der deutschsprachigen Literatur [Bildiri]. Begegnung mit dem „Fremden“, Grenzen-TraditionenVergleiche. Akten des VII. Internationalen Germanisten-Kongress Tokyo. München: Iudicium Verlag.

Kuruyazıcı, N. (2001). İki Kültür Arasında Bir Yazar: Renan Demirkan. (Ed.) Gurbeti Vatan Edenler: Almanca Yazan Almanyal Türkler (ss. 249-253). Ankara: Kültür Bakanlığı Yayınları.

Kuruyazıc1, N.(1992). Alman Okurları ve Türk Göçmen Yazınına Yeni Bir Bakış. Hürriyet-Gösteri, Sanat Edebiyat Dergisi "Almanya'da Yazan Türkler" Eki, 144, 7-10.

Lange, A. (1996). Migrationsliteratur - Ein Gegenstand der interkulturellen Paedagogik.

Frankfurt: IKO Verlag.

Lintfert, M. (1998). Migrantenbiographien. Kultur und Migration als Inhalte in der Deutsch als Fremdsprache-Ausbildung. Frankfurt: Peter Lang Verlag.

Rösch, H. (1992). Migrationsliteratur im interkulturellen Kontext. Eine didaktische Studie zur Literatur von Aras Ören, Aysel Özakın, Franco Biondi und Rafik Schami. Frankfurt: IKO Verlag.

Or, B. (1994). Überlegungen zur Fremdenthematik am Beispiel "Leben im gelobten Land Gastarbeiterporträts" von Max von der Grün. (Yayınlanmamış Yüksek Lisans Tezi). İstanbul: Marmara Üniversitesi, Sosyal Bilimler Enstitüsü.

Özcan, J. (2008). Yüksel Pazarkaya'nın Eserlerinde Eğitim Problemleri: Edebiyat Yardımı ile Kültürlerarası Eğitime Bir Katkı. (Yayınlanmış Yüksek Lisans Tezi). Çanakkale: Çanakkale Onsekiz Mart Üniversitesi, Sosyal Bilimler Enstitüsü.

Öztürk, A. O. (2002). Alamanya Türküleri; Türk Göçmen Edebiyatının Sözlü / Öncü Kolu, Ankara: Kültür Bakanlığı. "Zur Liedfolklore der türkischen Gastarbeiter in Deutschland," in: Europäische Ethnologien im neuen Millenium. Osteuropaeische Ethnologien auf neuen Wegen- Abschied vom Referatenorgan DEMOS, Hrsg.: Emmrich, Brigitte \& Moser Johannes. 
Öztürk, K. (1994). Das Frauenbild in den Werken der Deutschschreibenden Türkischen Autorinnen. (Yayınlanmamış Doktora Tezi). Ankara: Gazi Üniversitesi Sosyal Bilimler Enstitüsü.

Pazarkaya, Y. (2001). Yazın Açısından Almanya'nın Birleşmesi- Türk ve Alman Topluluklarının Kaynaşmasında Ayrışım. Karakuş, M. ve Kuruyazıcı N. (2001). Gurbeti Vatan Edenler; Almanca Yazan Almanyall Türkler. Ankara: Kültür Bakanlığı Yayınları.

(2004). Generationswechsel - Themenwandel. Durzak, M. ve

Nilüfer K. (2004). Die andere Deutsche Literatur, Istanbuler Vorträge. Würzburg: Königshausen\&Neumann Verlag.

Savaş, M. (2011). Karşılaştırmalı Yazınbilim Çerçevesinde Herta Müller, Elke Schmitter, Saliha Scheinhardt Ve Feridun Zaimoğlu'nun Birer Eserinde Kadın Imgesine Eleştirel Yaklaşım. (Yayınlanmamış Doktora Tezi). Adana: Çukurova Üniversitesi Sosyal Bilimler Enstitüsü.

Şen, F. M. (2001). Alev Tekinay Örneğinde Almanya'daki Türk Yazarların Eserlerinde Doğa. (Yayınlanmamış Yüksek Lisans Tezi) Eskişehir: Anadolu Üniversitesi Sosyal Bilimler Enstitüsü.

Tekinay, A. (1997). In drei Sprachen leben. S.27-33. in: Fischer, S. ve M. McG. (1997). Denn du tanzt auf einem Seil; Positionen deutschsprachiger MigrantInnenliteratur. Tübingen: Stauffenburg Verlag.

Thore, P. (2004). 'Wer bist du hier in dieser stadt, in diesem land, in dieser neuen welt'. Die Identitätsbalance in der Fremde in ausgewählten Werken der deutschsprachigen Migrantenliteratur. Uppsala: Verlag der Uppsala Universität.

Treibel, A. (2003). Migration in modernen Gesellschaften: Soziale Folgen von Einwanderung, Gastarbeit und Flucht. Weinheim/München: Juventa Verlag.

Tosun, A. F. (2006). Almanya'da Yaşayan Türk Yönetmenlerin Filmlerinde Göçmen Olgusu. (Yayınlanmamış Yüksek Lisans Tezi). İzmir: Dokuz Eylül Üniversitesi Güzel Sanatlar Enstitüsü.

Turaç, M. (2012). Fatih Akın'ın Filmlerinde Kimlik Temsilleri. (Yayınlanmamış Yüksek Lisans Tezi). Ankara: Gazi Üniversitesi Sosyal Bilimler Enstitüsü.

Uluç, T. F. (1996). Basında Türk ve Alman İmajı. (Yayınlanmamış Yüksek Lisans Tezi). İstanbul: Marmara Üniversitesi Sosyal Bilimler Enstitüsü.

Yalçın, N. (2011). Renan Demirkan'ın “Ü̧̧ Şekerli Demli Çay” Romanında Kültürlerarasıllı. (Yayınlanmış Yüksek Lisans Tezi). Ankara: Ankara Üniversitesi Sosyal Bilimler Enstitüsü.

Yavuz, G. D. (2007). Türkiye’nin Avrupa Birliğine Katılımı: Göçün Olası Rolü. (Yayınlanmış Yüksek Lisans Tezi). Istanbul: Sabancı Üniversitesi Sosyal Bilimler Enstitüsü.

Yıldız, M. H. (2010). Necla Kelek'in? Die Fremde Braut? ve Nuran Joerissen'in? Süsser Tee? İsimli Eserlerinde "Öz” ve "Yabancl” Kavramlarının 
İrdelenmesi. (Yayınlanmış Yüksek Lisans Tezi). Adana: Çukurova Üniversitesi Sosyal Bilimler Enstitüsü.

Zengin, E. (2010). Ein historischer Einblick in die Deutsch-Türkische Literatur und die Begriffe im Zusammenhang mit dieser Literatur. Hacettepe Üniversitesi Türkiyat Araştırmaları Dergisi, (12), 329-349.

Zengin, E. (2011). Berlin? Türk Göçmen Edebiyatında Bir Metropol: Aras Ören, Emine Sevgi Özdamar ve Yade Kara'nın Eserlerinde Mekân ve Kimlik. (Yayınlanmamış Doktora Tezi). Ankara: Hacettepe Üniversitesi Sosyal Bilimler Enstitüsü.

\title{
TURKISH-GERMAN MIGRATION LITERATURE IN GERMANY ON ITS FIFTIETH ANNIVERSARY
}

\begin{abstract}
This study investigates second generation period of Turkish German literature (also called as immigration literature) which began with laborer immigration from Turkey to Germany in 1960 s. The study initially defines immigration concept, explores how it was named in different ways, and historical development of Turkish - German immigration literature is described. Since the topic is limited, with second generation period, a writer Renan Demirkan and her work Üç Şekerli Demli Çay has been selected for this study. By means of this study it is aimed to investigate the concept of "immigration", to deepen this subject, and to the work $\ddot{U} c ̧$ Şekerli Demli Çay, which is selected to approach from different perspectives. Renan Demirkan and her work were studied in terms of questing for identity. The work reflects the characteristics of second generation immigration literature, and the main theme of this period which is the quest for identity. The study investigates the concepts of "longing for homeland" and "adaptation". Works of the period reflect deep meaning of this concept, feelings of the people who face a different culture in a different country, different traditions, and a different language. Finally the study describes how immigration literature has changed from its appearance to present time. Turkish -German literature was investigated in the context of text.
\end{abstract}

Keywords: Immigration, Guest-Worker Literature, Literature, the Second Generation, Renan Demirkan. 


\title{
LES OPINIONS DES ETUDIANTS SUR LE COURS « EVALUATION ET ADAPTATION DE MATERIELS PEDAGOGIQUES »
}

\section{Cihan AYDOĞU ${ }^{1}$}

\begin{abstract}
Öz: Eğitim fakültelerinin yabancı dil bölümlerinin öncelikli hedefi öğrencileri öğrenim gördükleri yabancı dili etkili bir şekilde öğretmeye hazırlamaktır. Bunun için de, öğrencilerin birçok kuramsal bilginin yanı sıra, bu bilgilerini sınayabileceği bir öğretim ortamına ihtiyacı vardır. Bu bağlamda, eğitim fakültesi bölümlerinin programlarında okul deneyimi ve öğretmenlik uygulaması dersleri yer almaktadır. Ancak sadece birer akademik dönemle sınırlı bu stajlar, öğretmenlik mesleğine hazırlanmada yetersiz kalabilmektedir. Dolayısıyla da öğretmen adaylarına bu gözlem ve uygulamaya dayalı stajlardan önce, yöntem derslerinde bilgilerini sınayabilecekleri bir ortamın yaratılması gerekmektedir. Yaparak öğrenme bu ortamı sağlayabilecek yöntemlerden biri olarak karşımıza çıkmaktadır. Bu çalışmada hedefimiz yaparak öğrenme yöntemini kullanarak bu amaca hizmet etmektir. Bu doğrultuda, Materyal Değerlendirme ve Uyarlama dersinde tek grup son-test modeline dayanarak Fransızca bölümü öğrencilerine özgün dokümanlardan hareketle çalışma yaprakları hazırlattık. Dersler haftada 3 saat olmak üzere toplam 12 hafta sürdü. İlk 4 hafta teorik bilgiler verildi. İzleyen 8 hafta boyunca uygulama çalışmaları gerçekleştirildi. Yaparak öğrenmenin öğrenciler üzerindeki etkilerini ölçmek amaciyla açık uçlu sorulardan oluşan bir anket uygulandı. Sonuç olarak, yaparak öğrenmenin öğrencilerde bir Fransızca yabancı dil dersi hazırlama konusunda birçok beceriyi geliştirdiği ve öğrencilerin özgüvenini desteklediği görülmüştür. Öğrencilerin yaşadıkları güçlükleri tespit etmek maksadıyla sorulan soruya verdikleri cevaplar değerlendirildiğinde ise yaparak öğrenme tekniğinin güçlükleri azaltma yönünde olumlu bir katkısı olduğu ancak yine de bazı güçlüklerin devam ettiği tespit edilmiştir.
\end{abstract}

Anahtar Sözcükler: Çalışma Yaprağı, Yaparak Öğrenme, Yabancı Dil, Materyal Hazırlama, Özgün Doküman, Öğretmen Adayı.

\section{Introduction}

L'objectif primordial des départements de langues des facultés de pédagogie est de former les futurs enseignants de langues étrangères. Pendant ce processus, les étudiants apprennent à planifier une situation d'apprentissage, à organiser des activités d'apprentissage, à faire des évaluations et à contribuer au

\footnotetext{
${ }^{1}$ Yrd. Doç. Dr., Anadolu Üniversitesi, Eğitim Fakültesi, Yabancı Diller Eğitimi Bölümü, Fransız Dili Eğitimi Anabilim Dalı. caydogdu@anadolu.edu.tr
} 